\title{
A GIS Approach to Locate a Small Size Biomass Plant Powered by Olive Pruning and to Estimate Supply Chain Costs
}

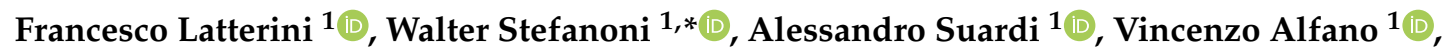 \\ Simone Bergonzoli ${ }^{2}\left(\mathbb{D}\right.$, Nadia Palmieri $^{1}{ }^{(\mathbb{D}}$ and Luigi Pari ${ }^{1}$ (D) \\ 1 Consiglio per la Ricerca in Agricoltura e l'Analisi dell'Economia Agraria (CREA), Centro di Ricerca \\ Ingegneria e Trasformazioni Agroalimentari, Via della Pascolare 16, 00015 Monterotondo, Italy; \\ francesco.latterini@crea.gov.it (F.L.); alessandro.suardi@crea.gov.it (A.S.); vincenzo.alfano@crea.gov.it (V.A.); \\ nadia.palmieri@crea.gov.it (N.P.); luigi.pari@crea.gov.it (L.P.) \\ 2 Consiglio per la Ricerca in Agricoltura e l'Analisi dell'Economia Agraria (CREA), Centro di Ricerca \\ Ingegneria e Trasformazioni Agroalimentari, Via Milano 43, 24047 Treviglio, Italy; \\ simone.bergonzoli@crea.gov.it \\ * Correspondence: walter.stefanoni@crea.gov.it; Tel.: +39-06-90675248
}

Received: 5 May 2020; Accepted: 29 June 2020; Published: 1 July 2020

\begin{abstract}
The valorization of agricultural residues plays a fundamental role in renewable energy production. Particularly, the management of olive orchards in Lazio region generates a considerable amount of biomass that is currently unexploited, but it could represent a valid source of solid biofuel for energy production in the Lazio region (Italy). Using a Geographic Information System (GIS) approach entirely based on open source software, five suitable areas (A, B, C, D and E) have been selected as eligible for hosting and feeding a 1 MWe power plant. Harvesting and transportation costs were also calculated. The harvesting operation costs were EUR $96.79 \mathrm{Mg}_{\mathrm{fm}}^{-1}$ in A, while they ranged from EUR $49.83 \mathrm{Mg}_{\mathrm{fm}}{ }^{-1}$ (E) up to EUR $56.51 \mathrm{Mg}_{\mathrm{fm}}{ }^{-1}$ (D) for the other sub-areas. Sub-area A showed also higher transport costs, EUR $21.55 \mathrm{Mg}_{\mathrm{fm}}{ }^{-1}$ while the same value ranged from EUR $14.75 \mathrm{Mg}_{\mathrm{fm}}{ }^{-1}$ (E) to EUR $16.59 \mathrm{Mg}_{\mathrm{fm}}^{-1}$ (B) in the other sub-areas. However harvesting costs resulted higher than those reported in the literature, mainly due to the low pruning yield per surface unit, an aspect which is directly related to the olive grove's management in the region where annual pruning is the usual practice. Future developments of the present study should encompass the social and environmental aspects of residual biomass supply chains herein proposed.
\end{abstract}

Keywords: renewable energy; pruning; harvesting; slope; suitable areas; Central Italy; Corine Land Cover

\section{Introduction}

Since the worldwide population is expected to increase up to 9 billion people by 2050 [1], the demand for food and energy will increase accordingly, generating competition for land use and energy sources. In fact, the cultivation of energy crops is gaining more and more interest around the world as a possible surrogate of crude oil products that could represent a competition for food land use.

In 2017, the domestic electricity production in Italy accounted for the $87 \%$ of inland demand [2] but only one third of it was produced from renewable sources such as hydroelectric $(11 \%)$, wind $(6 \%)$, and solar (8\%) power plants [3].

Biomass and waste resources accounted only for the $6 \%$ of the total national production of electricity. Since most of the production of the remaining share of electricity relies on imported fossil fuels, fostering the exploitation of domestic agriculture residues for energy production could help 
to reduce the national dependence on other countries for energy source and reduce the greenhouse effects too. Moreover, reducing energy production from fossil fuels is the key topic of the European Renewable Energy Directive (RED II, directive 2018/2001/EU) which seeks to address the problem by encouraging the agricultural residues exploitation.

Producing renewable energy from agricultural residues has indeed a double advantage, i.e., to turn biomass which actually has a disposal cost into an economic resource for farmers, without requiring additional land and competing with the food industry [4-7].

European, national and regional laws particularly encourage small size biomass power plants ( $\leq 1 \mathrm{MWe}$ ) powered by local biomass [8-10] like the Fiusis power plant situated in the south of Italy (Fiusis s.r.l, Calimera, Apulia). Fiusis represents a successful and unique case in Europe of short supply chain of local olive tree pruning used for electricity production [11]. It relays on an innovative logistic chain of the biomass suppling that is not bought from external enterprises as generally happens for conventional power plants. Instead, a Fiusis subsidiary harvest firm called "Ligna" is responsible for collecting the biomass produced during the pruning stage for feeding the power plant [11].

As in Apulia, olive growing is among the most important crops in the Lazio region (Central Italy), where 81,231 ha are engaged in such farming [12]. Here, tree pruning is generally carried out yearly (seldom every 2 years) generating a considerable amount of residue ranging from 1 to $5 \mathrm{Mg}_{\mathrm{fm}} \mathrm{ha}^{-1}$ [13]. Although the potential of such biomass has already been stated, pruning residues are still considered as a problem instead of a valid resource for energy production [14-16]. Thus, replicating Fiusis' approach in another Italian region like Lazio, where olive cropping is extensive, can produce positive effects on the economy as well as on the environment at both local and national scale.

Indeed, very few studies focused on the development of a biomass plant powered by agricultural residues in the Lazio region and no one has considered olive pruning in particular [17].

Certainly, the degree of the sustainability of a given biomass plant depends on several factors, such as: a regular and consistent biomass availability, well-designed logistics of feedstock supply, and optimal use of the resources [18-21]. Particularly, the location of the power plant is critical [22] and the Geographic Information System (GIS) is one of the most powerful and widely accepted tools for planning in agriculture and forestry sectors [23-26]. In fact, GIS permits us to combine both spatial and non-spatial factors such as the extractable biomass from forests and orchards, cost indicators and particular restrictions applied on a given area [27-29] to assess land suitability for the location of the biomass plant [30-32] and support the decision-making phase of the whole supply chains [19,33,34].

However, many of them relied on expensive commercial software which are also highly demanding in terms of computer performance. Moreover, few works included the harvesting operation analysis in the calculation of the supply chain costs [19].

Hence, this study aimed to provide the suitable locations of prospective small size power plants in the Lazio region (Figure 1) using olive pruning exclusively as feedstock, following the Fiusis model, applying a "user-friendly" GIS approach, which implies the usage of open-source software and medium sized hardware. Although the accuracy of open-source GIS software has already been stated [35], only a few works have relied on it for agriculture or forestry applications [36-38].

In details the first step consisted in the identification of the areas within regional territory which showed feasible characteristics for the implementation of a theoretical biomass plant. The second step is the localization of theoretical small size power plants according to the Regional Plan for Energy ("Piano Energetico Regionale" P.E.R. Lazio) [10]. Finally, the last step involved the estimation of the cost for harvesting, handling, loading and transportation of the biomass, taking the Fiusis and Ligna models as examples, i.e., the same plant enterprise which performs also the biomass collection operation.

Relying on realistic data, this study represents an innovative approach for dealing with agricultural residues management and sustainable energy production, providing agronomists, investors and policy makers with a handy and open access tool for drawing future strategies in the Lazio region. 


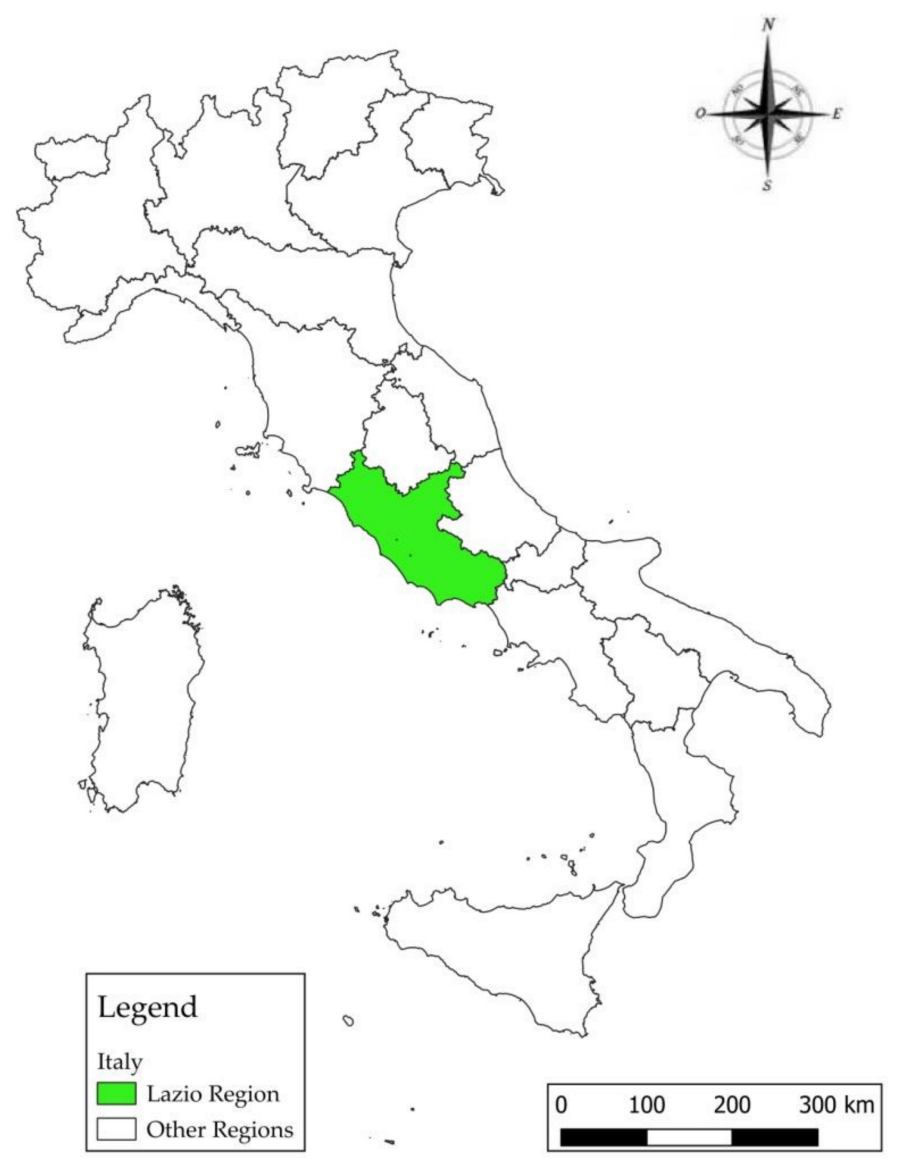

Figure 1. Lazio region localization.

Recent GIS Applications in Spatial Allocation of Biomass Power Plants in Europe

Several previous studies have identified GIS as a suitable and versatile tool to perform the spatial analysis needed for the location of a biomass power plant and of the related biomass supply chain $[23,39,40]$. Through this technology, it is indeed possible to capture, store, analyze, display and manipulate spatial data [41], also integrating them with non-spatial quantitative or qualitative data [23]. Considering this, much attention has been paid to such tools by scientific research in the renewable energy sector, with a particular focus on energy from biomass. Indeed, GIS, along with other methods such as Multi Criteria Decision Analysis, is able to face and solve different issues such as land availability and suitability, supply chain costs, and environmental impacts quantification and limitation [42].

Concerning the use of GIS in Europe during the last six years (2015-2020), many successful applications have been reported regarding the management of biomass for energy purposes.

Biomass availability from agriculture residues in Central Europe was analyzed by Haase et al. identifying cereal straw as a very interesting feedstock for energy production in those areas [43]. Similar findings were reported by Comber et al., who analyzed the possibility of exploitation of straw, along with cattle slurry and food waste, for the development of anaerobic digestion plants in United Kingdom, also integrating supply locations that minimize distances to demand sites in the simulation model [44]. Similarly, in Denmark, the economic and social aspects of the development of a biogas supply chain were analyzed by Franco et al. [45].

In Mediterranean areas, biomass availability for biogas production has been studied in Sicily (Italy), reporting that the region could produce $211,000 \mathrm{Mg}$ year $^{-1}$ of biomass, which can be converted into $15,373,000 \mathrm{~m}^{3}$ of biogas and 30,000 Mg of soil amendment, generating $23.1 \mathrm{GWh}$ of electricity [46,47]. Su Jeong and Ramírez-Gómez instead applied an MCDA analysis to optimize the location of biomass 
facilities in Spain concerning both forestry and agriculture biomass [20], whilst López-Rodríguez et al. performed similar studies in Southern-West Europe focusing only on forestry biomass [25].

Finally, concerning pruning availability and exploitation for bioenergy production, an interesting study by Delivand et al. was performed in Apulia (Italy). The authors focused on the development of a supply chain for both cereal straw, vineyard pruning and olive one identifying the optimal location of theoretical biomass plants, also estimating supply chain costs and Green House gases (GHG) emissions [19].

\section{Materials and Methods}

\subsection{Software and Hardware Used for the Study}

The software used during the study was the open source Quantum GIS ver. 3.10 [48]. A personal computer with processor Intel Core i5 $2.20 \mathrm{GHz}$, a graphics processing unit (GPU) NVIDIA GeForge310, and $6.0 \mathrm{~Gb}$ RAM was used for the study. The minimum system and hardware requirements are: Core i3 2.7 Ghz Processor, 1 Gb Graphic card, 2 Gb Memory RAM, and Windows 7-10 OS [49].

\subsection{Average Pruning Biomass and Harvesting Scenarios}

An average pruning yield for Central Italy of $2.18 \mathrm{Mg}_{\mathrm{fm}} \mathrm{ha}^{-1} \mathrm{y}^{-1}$ and moisture content of $41 \%$, were considered for the study [14,50]. Regarding the harvesting operations, data influencing both the supply chain costs and the amount of available biomass were taken into account.

In particular, the performance of the harvesting systems used by the Ligna firm were considered in this study according to the results obtained during the European project AGROinLOG [51]; thus identifying two harvesting systems which correspond to three different harvesting scenarios.

The first system consists in pruning harvesting with a towed shredder. This system also requires a preliminary raking operation [52]. In detail, pruning residues are raked and then comminuted by the shredder which unload the hog fuel at a landing site out of the field. Here, a lifter loads on the truck for the transport to the plant. According to the Fiusis and Ligna models, the timeframe between biomass collection and loading-transport varies generally between 15 to 30 days. Considering such a short timeframe and referring to the Fiusis example (on field storage costs covered by the farmer) no intermediate storage costs are considered in the estimation of supply chain costs. The towed shredder system can work on slopes up to $25 \%$ and, with such a system, average collection loss reaches $25 \%$. The first harvesting scenario (SF) consisted of a shredder working on flat slopes (up to $5 \%$ ) and the second with the towed shredder working on slopes up to $25 \%$ (SS). This harvesting system showed different harvesting costs per surface unit, depending on flat or hilly slopes applications [52].

In the second harvesting system, the biomass is comminuted using a stationary chipper. In this system, the pruning residues are bunched close to the chipper by a tractor with fork. Then, a hydraulic loader feeds the chipper which, in turn, unloads the comminuted material on the ground. Then a lifter collects and load it on a truck for transport [11]. This represent the third harvesting scenario (SC) which consists of the use of the stationary chipper and it is considered for a slope ranging from 25 to $30 \%$. This scenario presents substantially higher costs per surface unit if compared to the other two but, on the other hand, it does not produce significant biomass loss during the harvesting [11].

Slopes higher than $30 \%$ were not considered as suitable for mechanical harvesting of pruning residues. A summary of the main parameters of the various harvesting scenarios used in this study are reported in Table 1. It is important to underline that in the following paragraphs of the present paper, the term "harvesting" refers to biomass collection, handling and loading on the truck. 
Table 1. Main characteristics of the harvesting scenarios.

\begin{tabular}{|c|c|c|c|c|c|c|}
\hline \multirow{3}{*}{$\begin{array}{c}\begin{array}{c}\text { Slope } \\
\text { Range (\%) }\end{array} \\
0-5 \%\end{array}$} & \multirow{3}{*}{$\begin{array}{c}\begin{array}{c}\text { Harvesting } \\
\text { Scenario }\end{array} \\
\text { SF }\end{array}$} & \multicolumn{2}{|c|}{ Machineries and Operations } & \multirow{3}{*}{$\begin{array}{c}\begin{array}{c}\text { Harvesting } \\
\text { Costs per } \\
\text { Surface Unit } \\
\text { (EUR ha }^{-1} \text { ) }\end{array} \\
72.90\end{array}$} & \multirow{3}{*}{$\begin{array}{c}\text { Harvesting } \\
\text { Loss (\%) }\end{array}$} & \multirow{3}{*}{$\begin{array}{c}\text { References } \\
{[11,52]}\end{array}$} \\
\hline & & & $\begin{array}{c}\text { Shredding, handling and } \\
\text { loading }\end{array}$ & & & \\
\hline & & $\begin{array}{l}\text { pruning rake } \\
+44 \mathrm{~kW} \\
\quad \text { tractor }\end{array}$ & $\begin{array}{l}\text { towed shredder }+96 \mathrm{~kW} \\
\text { tractor }+90 \mathrm{~kW} \text { lifter }\end{array}$ & & & \\
\hline \multirow[t]{2}{*}{$5-25 \%$} & \multirow[t]{2}{*}{ SS } & Raking & $\begin{array}{c}\text { Shredding, handling and } \\
\text { loading }\end{array}$ & \multirow[t]{2}{*}{87.60} & \multirow[t]{2}{*}{25} & \multirow[t]{2}{*}[11,52]{} \\
\hline & & $\begin{array}{l}\text { pruning rake } \\
\quad+44 \mathrm{~kW} \\
\quad \text { tractor }\end{array}$ & $\begin{array}{l}\text { towed shredder }+96 \mathrm{~kW} \\
\text { tractor }+90 \mathrm{~kW} \text { lifter }\end{array}$ & & & \\
\hline \multirow{2}{*}{$25-30 \%$} & \multirow{2}{*}{ CS } & Bunching & $\begin{array}{c}\text { Comminuting, handling and } \\
\text { loading }\end{array}$ & \multirow{2}{*}{230.38} & \multirow{2}{*}{0} & \multirow{2}{*}{ [11] } \\
\hline & & $\begin{array}{l}66 \mathrm{~kW} \\
\text { tractor }\end{array}$ & $\begin{array}{l}\text { stationary chipper }+ \\
\text { hydraulic loader }+126 \mathrm{~kW} \\
\text { tractor }+90 \mathrm{~kW} \text { lifter }\end{array}$ & & & \\
\hline
\end{tabular}

\subsection{Identification of Suitable Areas}

GIS data were geo-referenced in ED50UTM33 coordinate.

The first step of the GIS procedure was the identification of the suitable zones for the biomass supply chain implementation. Starting from the size of the supply basin of Fiusis (about $10 \mathrm{~km}$ radius), the map of Lazio region (vector file) was firstly subdivided into "sub-areas" of approximately $400 \mathrm{~km}^{2}$ each.

Subsequently, starting from a $20 \mathrm{~m}$ pixel DTM (Digital Terrain Model) [53], a slope map of Lazio region was developed (map's name: Lazio_Slope) and then reclassified assigning value "1" to slope up to $30 \%$ and " 0 " to higher slopes (map's name: Lazio_Slope_Reclassified). In parallel, the regional Corine Land Cover Map (year 2016) was used to extract regional olive groves map [54]. The overlay between the reclassified slope map and the olive groves map led to the development of the harvestable olive grove map, according to the three harvesting scenarios reported in Table 1 . This last map was successively converted in vector format and overlaid with the sub-areas map in order to identify the harvestable olive grove surface in each sub area. The sampling of the previously created Lazio Slope map allowed us to know the slope of the various harvestable olive groves in each sub area and so the applicable harvesting scenario. Moreover, it was also possible to estimate the pruning amount in each sub area considering $2.18 \mathrm{Mg}_{\mathrm{fm}}$ ha $^{-1}$ for CS olive groves, considering no harvesting loss, and $1.64 \mathrm{Mg}_{\mathrm{fm}} \mathrm{ha}^{-1}$ for SF and SS ones, thus considering $25 \%$ harvesting losses, as reported in Table 1.

Relying on that information, it was possible to identify the suitable areas according to the following criterion: a suitable sub area is the area where the harvestable amount of pruning biomass every year is at least $8000 \mathrm{Mg}_{\mathrm{fm}}$. This threshold of $8000 \mathrm{Mg}_{\mathrm{fm}}$ is taken from data from Fiusis, which is annually powered by this amount of biomass [55].

\subsection{Theoretical Small Size Biomass Plants Localization}

The second step consisted in the localization of one small size biomass plant ( $\leq 1 \mathrm{MWe}$ ) powered only by olive pruning in each sub area.

First of all, a "Constraints" layer was built by merging into a single vector file all those zones having environmental (both Protected Natural Areas and Natura 2000 zones), landscape or hydrogeological constraints [32]. In these areas, the biomass plant was considered not allowed. It is important to underline that in Italy, there is no regulation which clearly forbids the localization of a biomass plants in constrained areas, neither at the national nor at the regional level. Nevertheless, authors maintained a precautionary approach in order to guarantee as less impact as possible on both environment and landscape. Thus, the areas affected by such constraints were excluded. Consequently, a "Restrictors" 
layer was created [32], thereby showing the suitable areas for the location of the biomass plant. These areas are the ones with slopes lower than $15 \%$, with distance to road network lower than $300 \mathrm{~m}$ and distance to electric power lines lower than $500 \mathrm{~m}$. The vector difference between "Restrictors" and "Constraints" identified the possible areas for the plant localization.

Finally, photointerpretation of Google satellite images, along with the Corine Land Cover map of the region, allowed to spot on the map, the location of a single power plant unit per single sub area, carefully excluding the non-industrial areas as suggested by the P.E.R. Lazio [10].

A view of some of the layers used in the GIS procedure is given in Figure 2.

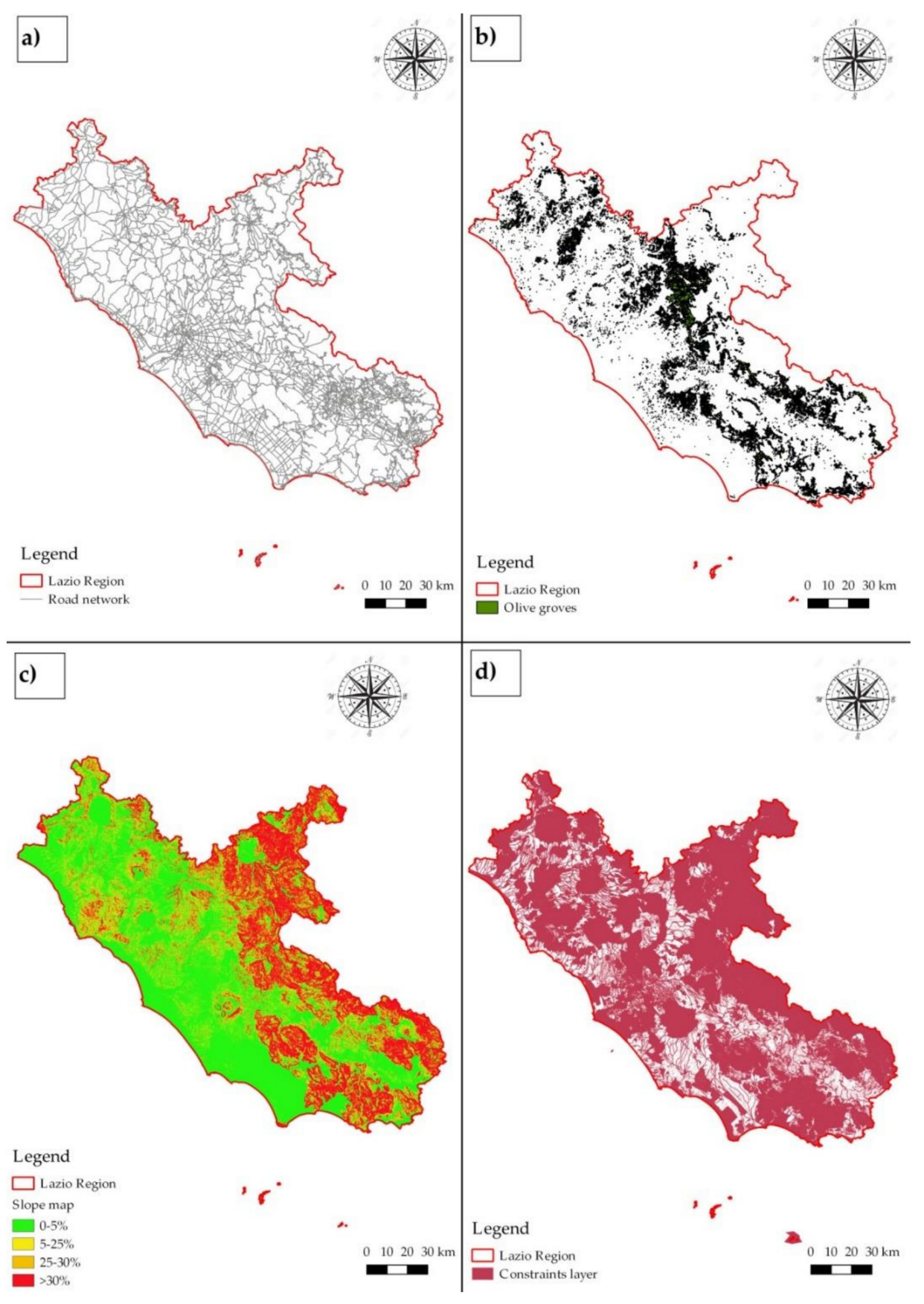

Figure 2. (a) regional road network; (b) olive groves map; (c) slope map; (d) Constraints layer. 


\subsection{Estimation of Supply Chain Costs}

Firstly, it is necessary to explain that the Fiusis model is based on a short supply chain with a very short period of intermediate storage of the biomass. In particular, comminuted biomass storage takes place in the field for a period which generally ranges from 15 to 30 days and this material is brought to the plant when it is needed. In this way, storage costs, which are low compared to the other operations of the supply chain [56], are covered by the farmers who accept Fiusis to collect their pruning; so, in this simulation storage costs are not taken into consideration because they do not represent a cost item for the biomass plant.

Concerning the last part of the GIS procedure, a 10 hectares grid was overlapped to each suitable sub area. Each cell of the grid represented one "plot". The intersection between the grid and the harvestable olive groves map allowed us to know the harvestable olive groves surface in each plot. Therefore, in each plot the information regarding olive groves surface, slope (so applied harvesting scenario) and pruning yield was provided. Applying the costs per surface unit showed in Table 1 for the various harvesting scenarios it was possible to assess, also, the harvesting costs for each plot.

Successively, the estimation of transport costs, assuming the hypothesis of using an 18-ton truck to carry out such operation, was performed. Transport cost per biomass and distance unit was considered equal to EUR $1.175 \mathrm{Mg}_{\mathrm{fm}}{ }^{-1} \mathrm{~km}^{-1}$ [11].

In the next step, the data of each plot were assigned to the plot's centroid. Simultaneously, the road network shapefile was cleared out by deleting paths, footways and residential roads, and a maximum travel speed was assigned to each road according to Italian roads' speed limits, i.e., $50 \mathrm{~km} \mathrm{~h}^{-1}$ for urban roads, $70 \mathrm{~km} \mathrm{~h}^{-1}$ for main roads and $80 \mathrm{~km} \mathrm{~h}^{-1}$ for motorways [36].

Subsequently, the fastest pathway from each plot's centroid to the biomass plant was calculated for each suitable sub area trough "Network analysis" tool [57]. Thus, transport costs estimation was performed by multiplying the obtained travel distance for the plot's pruning yield and the previously reported transport cost of EUR $1.175 \mathrm{Mg}_{\mathrm{fm}}{ }^{-1} \mathrm{~km}^{-1}$. The information regarding the supply chain costs for each plot was obtained by adding harvesting and transport costs. A summary of the overall procedure is given in Figure 3. 


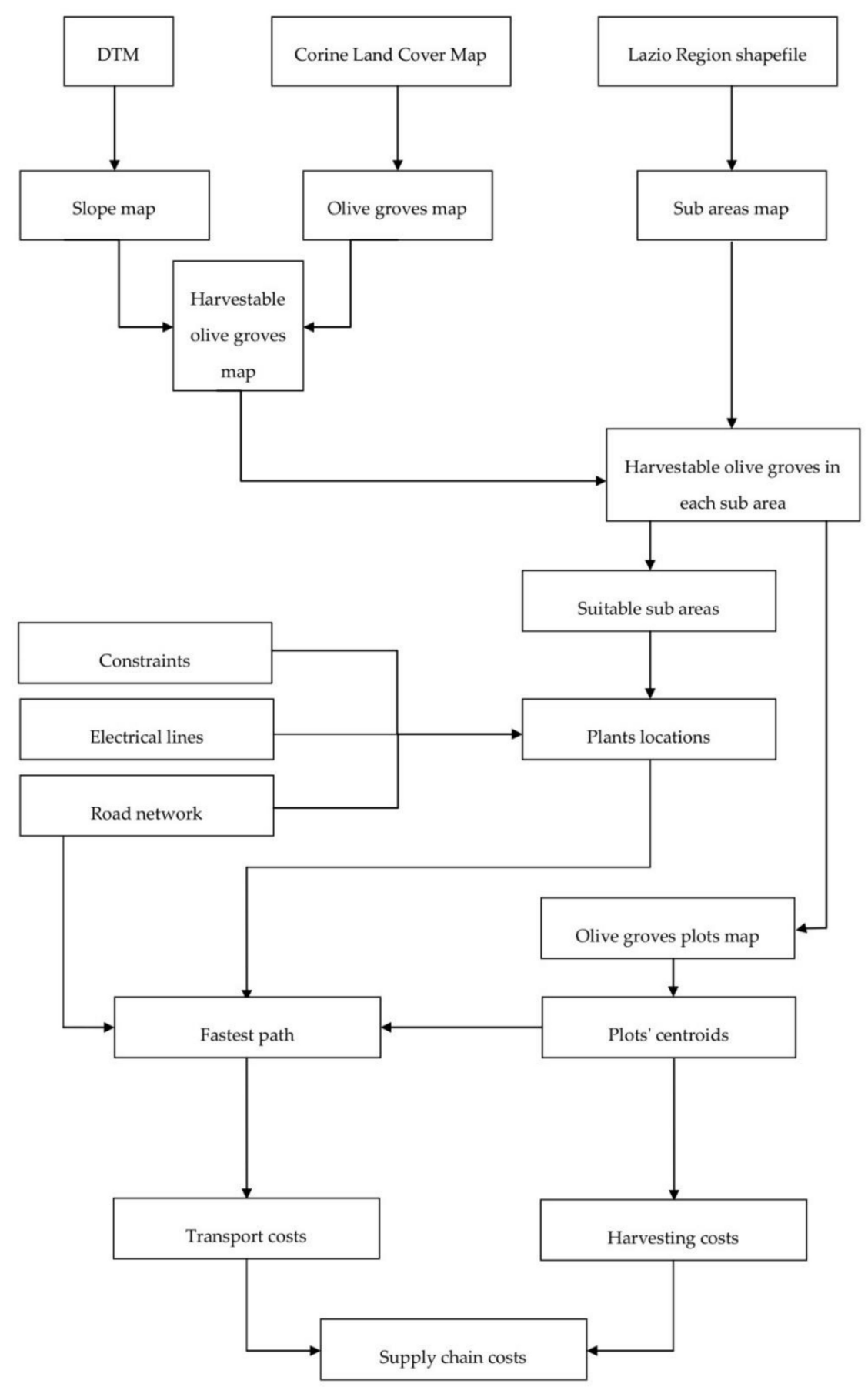

Figure 3. Graphical block diagram of the GIS procedure.

\section{Results}

\subsection{Identification of Suitable Sub-Areas and the Respective Main Characteristics}

According to the previously reported definition, i.e., a sub area of about $400 \mathrm{~km}^{2}$, in which there are at least $8000 \mathrm{Mg}_{\mathrm{fm}}$ of harvestable pruning residues, five sub-areas were identified as suitable for the implementation of a pruning supply chain capable to fuel a 1 MWe biomass plant (Figure 4). Figure 4 also shows the location of existing biomass power plants with sizes higher than 0.5 MWe reported in the region, as well as the position of the GIS-planned power plant for each suitable sub-area. 

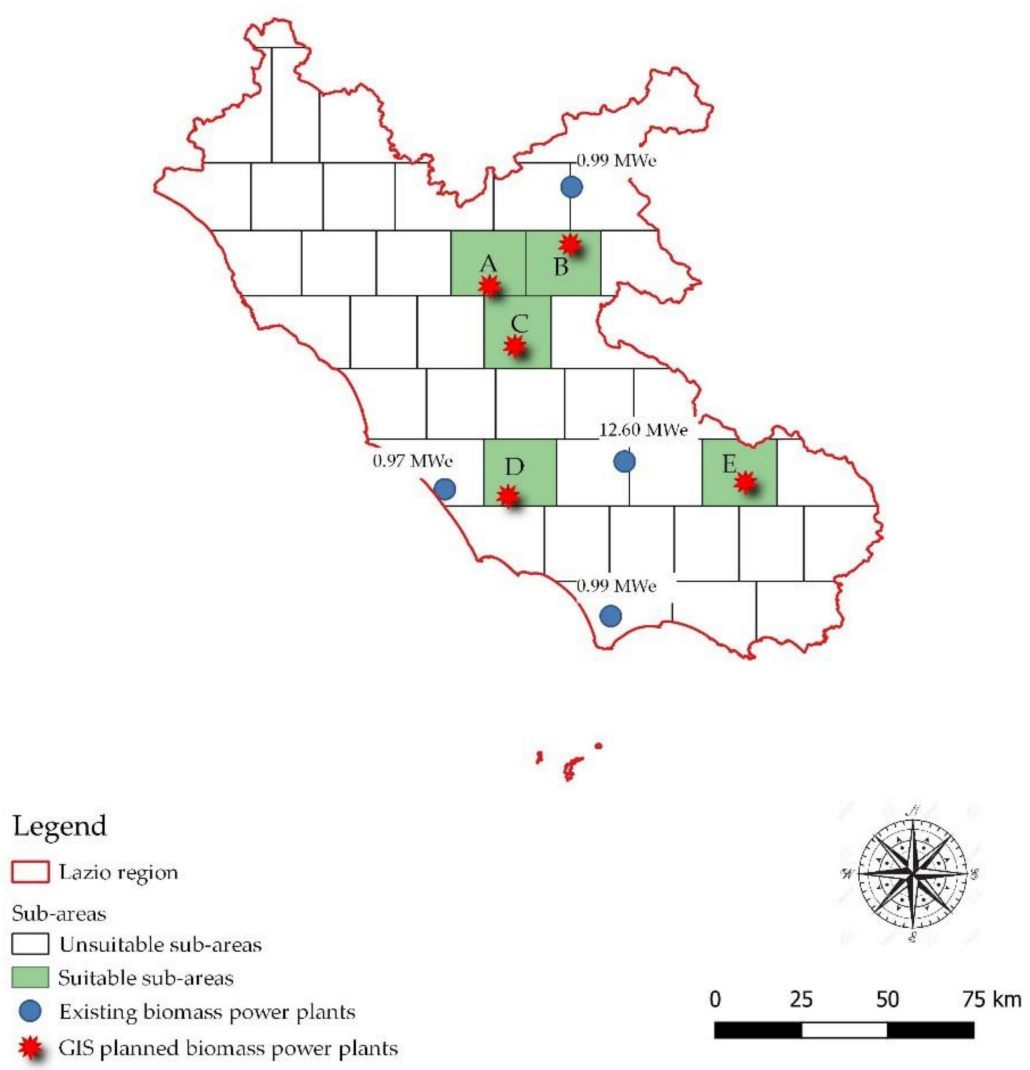

Figure 4. Sub-areas identified as suitable for the implementation of the pruning supply chain, existing biomass power plants in the region (blue dots), and location of the theoretical plant for each sub-area (red stars).

Total harvestable olive groves surface and yearly harvestable pruning availability in each suitable sub-area are given in Table 2. $\mathrm{B}$ and $\mathrm{C}$ areas showed a pruning yield values twice as high as $8000 \mathrm{Mg}_{\mathrm{fm}}$ required as minimum productivity for feeding the power plant. Meanwhile, pruning availability in areas $\mathrm{A}, \mathrm{D}$ and $\mathrm{E}$ is similar to the previous value set as threshold.

Table 2. Harvestable pruning yield and harvestable olive groves surface for each suitable sub-area.

\begin{tabular}{|c|c|c|}
\hline Sub-Area & $\begin{array}{l}\text { Yearly Harvestable Pruning Availability } \\
\left(\mathrm{Mgfm} \cdot \mathrm{year}^{-1}\right)\end{array}$ & Total Olive Groves Surface (ha) \\
\hline $\mathrm{A}$ & $11,162.18$ & 5396.01 \\
\hline $\mathrm{B}$ & $17,246.13$ & $10,448.09$ \\
\hline $\mathrm{C}$ & $19,838.51$ & $12,062.10$ \\
\hline $\mathrm{D}$ & 9664.76 & 5753.62 \\
\hline $\mathrm{E}$ & 8979.98 & 5483.13 \\
\hline
\end{tabular}

Focusing on the harvesting scenarios depicted in Figure 5, it is evident that the SS system can be applied extensively in B, C, D and E, while in A there is a substantial predominance of the CS harvesting system. Instead, SF provides limited contribution with the highest share (13.53\%) reported only in C. 

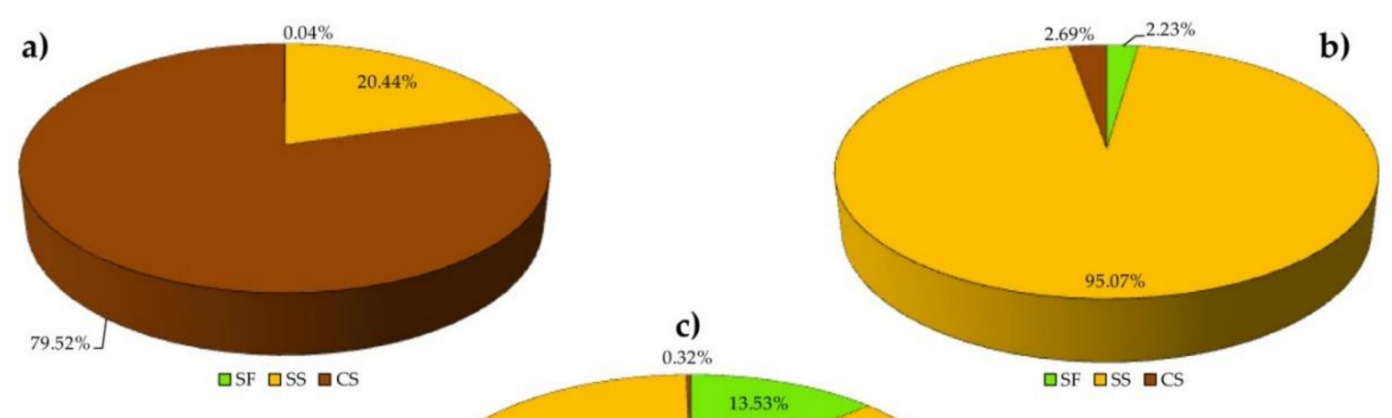

d)
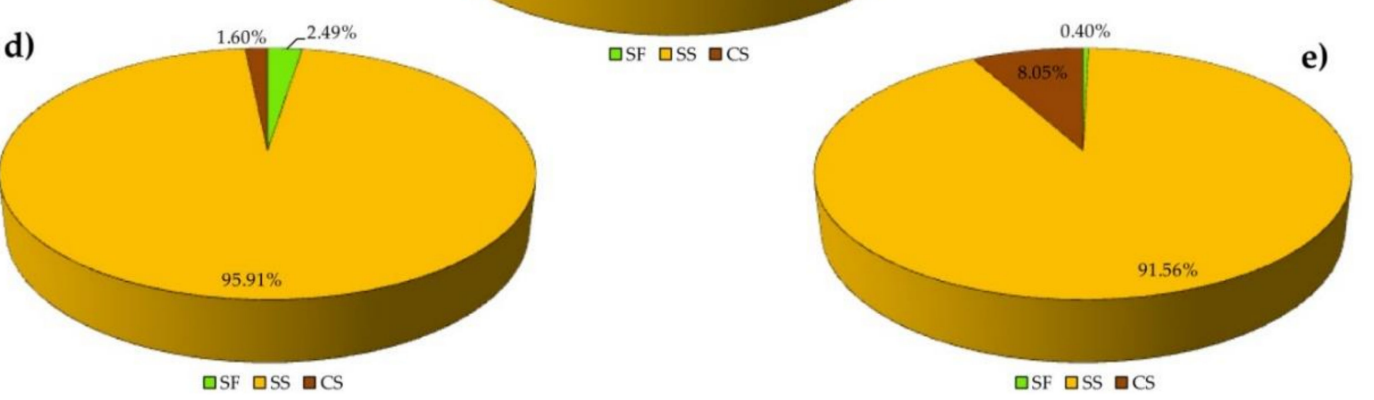

Figure 5. Harvesting scenarios percentage in each suitable sub-area. (a) A sub-area; (b) B sub-area; (c) C sub-area; (d) D sub Area; (e) E sub-area.

\subsection{Estimation of Supply Chain Costs}

The comparison of the supply chain costs among the various suitable sub-areas is given in Figure 6. Noticeably, there is a substantial difference between area A and the others. Particularly, sub-area A showed harvesting costs substantially higher in comparison to the others sub areas and higher transport cost as well.

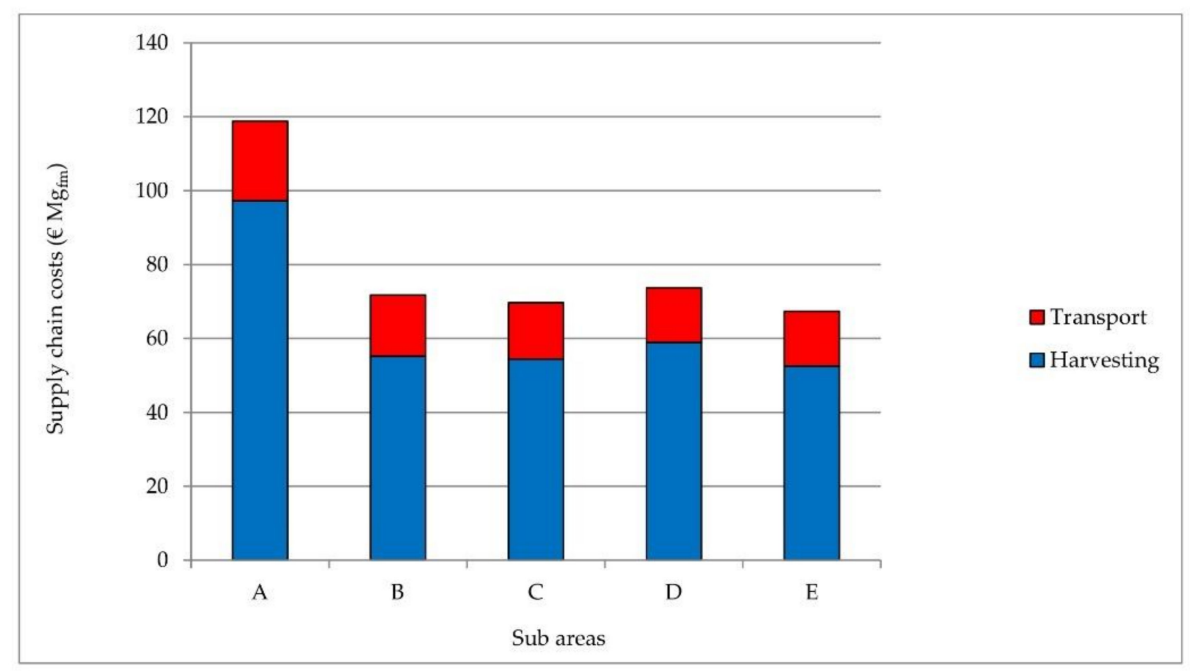

Figure 6. Supply chain costs for each suitable sub-area (harvesting, handling, loading and transport costs). 
The harvesting, handling and loading operations costs were EUR $97.23 \mathrm{Mg}_{\mathrm{fm}}{ }^{-1}$ in $\mathrm{A}$, while they ranged from EUR $52.55 \mathrm{Mg}_{\mathrm{fm}}^{-1}$ (E) to EUR $58.95 \mathrm{Mg}_{\mathrm{fm}}{ }^{-1}$ (D) for the other sub-areas. Indeed, the large use of CS harvesting system in A led to a substantial increase in the harvesting costs.

Sub-area A also showed higher transport costs, EUR $21.55 \mathrm{Mg}_{\mathrm{fm}}{ }^{-1}$ while the same value ranged from EUR 14.75 $\mathrm{Mg}_{\mathrm{fm}}{ }^{-1}$ (E) to EUR $16.59 \mathrm{Mg}_{\mathrm{fm}}{ }^{-1}$ (B) in the other sub-areas. Such difference depends on the transport distance, which in A resulted as being longer. In particular, the average transport distance for A was $22.46 \mathrm{~km}$, while it ranged from $12.98 \mathrm{~km}$ (E) to $15.85 \mathrm{~km}$ (B) among the other sub-areas.

\section{Discussions}

The analysis of the obtained results permitted to better refine the identification of the most suitable zones, in Lazio region, for the theoretical pruning supply chain implementation. For instance, sub-area A showed higher costs for both transport and harvesting. Particularly, the latter phase is far more responsible for the remarkable increase in the costs, dimming the possibility to include it within a practical and feasible plan for the development of a proper supply chain. In fact, the topography of the territory requires an extensive use of the most expensive harvesting scenario, i.e., CS, with the consequent increase in the harvesting costs. Moreover, the hilly-mountainous morphology of this sub-area exhibited poor reliability of the road network, this determined the increase in the length of the distance to drive and consequently, the transportation costs as well.

The B, C, D and E sub-areas instead showed very similar costs per biomass unit for both harvesting and for transport. However, there is an important consideration to be had. In fact, as reported in Table 2, the D and E sub-areas showed an average pruning yield just slightly higher than the $8000 \mathrm{Mg}_{\mathrm{fm}}$ which represented the threshold value for being considered as a suitable sub-area. So, in order to ensure the sufficient supply of biomass for feeding the power plant, all olive groves' owners in the sub-area are supposed to provide their contribution to the supply chain. Practically, this is not always true. For instance, Fiusis acknowledged that it can gather approximately $30 \%$ of the total annual biomass available in its supply basin [55], as not all farmers contribute to the supply of biomass. Hence, the overall estimated supply chain costs in $B$ and $C$ resulted as more trustable in the view of future development of the pruning supply chain. While D and E seem more suitable for a further smaller biomass plant.

Interestingly, B and C sub-areas lays adjacent, actually offering the possibility to be considered as a unitary source of biomass for feeding a bigger biomass plant. However, the European and National policies along with the specific Regional Directives strongly encourage smaller biomass plants. Such an approach seeks to make the local population benefit from the transformation of a burden, such olive pruning management, into energy. Therefore, in order to be in compliance with all the guidelines dictated by the regulations at the different levels drawn by environment and energy policy making, the development of two distinct biomass plants is the most preferable option.

Before trying to make a comparison with previous studies' results, it is important to underline that there are few examples in the literature with which to make a comparison with the present study, because, as reported by Palmieri et al. [55], Fiusis represents a very particular power plant in the European context.

Focusing on supply chain costs, comparing the results of this simulation with a similar study [19] and applicative examples, it is possible to notice how the present work showed substantially higher values. Excluding the A sub-area, which, as already reported above, showed very high costs, the result of the simulation reported for the other four sub-areas' supply chain costs was in the order of EUR $65.00-70.00 \mathrm{Mg}_{\mathrm{fm}}{ }^{-1}$. Delivand et al. [19], in a simulation of olive pruning supply chain costs in Southern Italy, reported a range of EUR $36.00-39.00 \mathrm{Mg}_{\mathrm{fm}}{ }^{-1}$, so considerably lower values. Similarly, the price of EUR $38.69 \mathrm{Mg}_{\mathrm{fm}}{ }^{-1}$ was reported by Suardi et al. in the Fiusis case $\mathrm{Mg}_{\mathrm{fm}}$ [11].

Such aspects could represent an obstacle for the development of a pruning supply chain in the Lazio region. The higher cost obtained is due to the different management system applied in olive groves which affects negatively the pruning yield per surface unit. In fact, in the Apulia region, 
the pruning operation is usually carried out every three years [55] and the pruning yield is usually in the range of $4-7 \mathrm{Mg}_{\mathrm{fm}} \mathrm{ha}^{-1}$ year $^{-1}[11,58]$, thus substantially higher than in the Lazio context. Therefore, when the costs per unit of biomass in the Lazio supply chain are calculated, higher values are unavoidable since the harvesting costs per surface unit are considered as fixed. Obviously, collecting the biomass in a hardly accessible field is more costly than accomplishing the same task on flat lands, but a certain amount of cost increase has to be tolerated. Certainly, if a real biomass power plant is to be built, more specific tests are encouraged in order to better discriminate the maximum slope acceptable, and a cost-benefit analysis must be performed. So far, a possible solution to reduce the supply chain costs in the B and C sub-areas is to avoid collecting olive grove pruning in fields with slopes higher than $25 \%$, thus excluding the most expensive harvesting scenario (CS). Moreover, it is important to consider that the efficiency of the machinery is not constant, but may change according to the tractor driver, the quality of the biomass collected and the ground conditions. Thus, all the regulations of the machine should be performed carefully, as, for instance, the regulation of the pick-up system and the optimization of the raking operation $[58,59]$ could significantly decrease the biomass loss and, consequently, the supply chain costs. In particular, considering no biomass losses for SS and SF harvesting scenarios and excluding olive groves with slopes higher than $25 \%$ from the supply chain, the overall costs would decrease to EUR $49.83 \mathrm{Mg}_{\mathrm{fm}}{ }^{-1}$ and EUR $52.54 \mathrm{Mg}_{\mathrm{fm}}{ }^{-1}$ for B and C, respectively. Despite their being higher than those reported for the Fiusis supply chain [11], or in similar studies in another context [19], they are close to the price of wood chips obtained from forest maintenance operations (i.e., EUR $50 \mathrm{Mg}_{\mathrm{fm}}{ }^{-1}$ referred to the purchase of a full cargo truck, VAT excluded, without transport) [60]. Moreover, another aspect to be highlighted is the fact that pruning mulching, which is the common practice adopted for residue management in Lazio, costs EUR $140.00 \mathrm{ha}^{-1}$, which is actually covered by the farmer and corresponds to EUR $64.00 \mathrm{Mg}_{\mathrm{fm}}{ }^{-1}$ considering the average olive pruning yield in the study area [61]. So, another possibility to reduce the cost of the supply chain for the biomass plant is to look for a deal with the various farmers, who could pay a certain amount of money to the biomass plant per biomass unit-obviously substantially lower than the actual price for mulching - in order to collect the pruning residues.

To summarize, the result of this preliminary simulation of a theoretical olive pruning supply chain in the Lazio region, able to feed a $\leq 1$ MWe biomass plant, showed that this zone of Central Italy presents interesting areas for this aim. However, the supply chain costs estimation reported higher values than similar applicative examples and simulations. Thus, the real feasibility of the biomass supply chain implementation in that zone has to be further investigated. Particularly, additional aspects related to all three pillars of sustainability (economy, environment and society), also integrating Life Cycle Assessment (LCA) [62] or Sustainability Impact Assessment (SIA) [63,64] approaches, have to be taken into account. The valorization of agriculture residues, from an energetic point of view, does not lead only to economic or environmental positive externalities but also to social ones [65-67]. In fact, a Fiusis-like power plant is an opportunity for creating new jobs directly and indirectly, if all the collateral activities are taken into account. Besides, it is very important to not underestimate the positive contribution of such new activities, acting as valid tools for fighting the phenomenon of the abandonment of rural areas in Italy [68].

Another important aspect of the present paper is the applied GIS procedure, which is fully developed with open source GIS software and with medium performing computer. This GIS approach is more "user-friendly" than the ones found in literature, providing all the stakeholders, for example agronomists or public servants, with a handy tool for drawing future strategies for bio-fuel supply chain development. This procedure is, in fact, applicable not only to pruning biomass but also to other agricultural residues or dedicated energy crops.

Obviously, it represents a first approach to the implementation of a real supply chain, and further steps are certainly needed in order to switch from preliminary study to operative planning. 


\section{Conclusions}

The exploitation of the residual biomass produced by olive pruning management could significantly contribute to achieving the challenging environmental goals set by the European policy for the next decades. However, in order to guarantee the beneficial effects of applying such strategy, the whole supply chain has to be managed properly for the successful running of the power plant. In fact, transportation costs and feedstock availability have been limiting factors for the development of similar supply chains in the past, and GIS can help to provide reliable data for preliminary planning.

The present study aims to provide stake holders and policy makers with a handy tool for assessing, at least at the very first step of the decision making, the possibility and the location of a biomass power plant at regional scale in the Centre of Italy. An open source GIS was used in order to discriminate, by the field's slope, the harvestable area in the Lazio region capable of providing the minimum biomass required for running the power plant all year round. Environmental, landscape and hydrogeological constraints were taken into account when defying the suitable area for locating the power plant, thus five macro areas were selected. Costs for harvesting and transportation were also included, providing reliable base data to draw the attention of investors and policy makers.

This represents a preliminary analysis, and deeper investigation is needed in the subsequent steps of the planning process. The future development of the present study could focus on the possibility of integrate the present procedure with indicators about environmental and social externalities of residual biomass supply chains.

Author Contributions: Conceptualization, F.L., and W.S.; methodology, F.L.; validation, A.S. and V.A.; data curation, F.L., N.P., W.S., A.S., V.A. and S.B.; writing-original draft preparation, F.L. and W.S.; writing-review and editing, F.L., W.S., A.S., V.A., S.B., N.P. and L.P.; supervision, A.S., V.A. and L.P.; funding acquisition, L.P. All authors have read and agreed to the published version of the manuscript.

Funding: The work was performed in the framework of the project Suscace ("Supporto Scientifico alla Conversione Agricola verso le Colture Energetiche").

Acknowledgments: The authors wish to thank FIUSIS company (Calimera, LE, Italy) for granting the data about the company.

Conflicts of Interest: The authors declare no conflict of interest. The funders had no role in the design of the study; in the collection, analyses, or interpretation of data; in the writing of the manuscript, or in the decision to publish the results.

\section{Abbreviations}

$\begin{array}{ll}\text { GIS } & \text { Geographic Information System } \\ \mathrm{Mg}_{\mathrm{fm}} & \text { Fresh matter ton } \\ \text { SF } & \text { Shredder on flat slope } \\ \text { SS } & \text { Shredder on hilly slope } \\ \text { CS } & \text { Chipper on hilly slope } \\ \text { DTM } & \text { Digital terrain Model } \\ \text { SIA } & \text { Sustainability Impact Assessment } \\ \text { LCA } & \text { Life Cycle Assessment } \\ \text { MCDA } & \text { Multi Criteria Decision Analysis } \\ \text { GHG } & \text { Green House Gases }\end{array}$

\section{References}

1. FAO. Global agriculture towards 2050. In How to Feed World; FAO: Rome, Italy, 2009. [CrossRef]

2. EUROSTAT. Supply, Transformation and Consumption-Commodity Balances. Available online: https: //appsso.eurostat.ec.europa.eu/nui/show.do (accessed on 16 April 2020).

3. ISTAT. Gross Electric Energy Production from Renewable Energy Sources. Available online: http://dati.istat. it/Index.aspx?QueryId=20144\# (accessed on 16 April 2020).

4. Bergonzoli, S.; Suardi, A.; Rezaie, N.; Alfano, V.; Pari, L. An innovative system for Maize Cob and wheat chaff harvesting: Simultaneous grain and residues collection. Energies 2020, 13, 1265. [CrossRef] 
5. Suardi, A.; Saia, S.; Stefanoni, W.; Gunnarsson, C.; Sundberg, M.; Pari, L. Admixing Chaff with Straw Increased the Residues Collected without Compromising Machinery Efficiencies. Energies 2020, 13, 1766. [CrossRef]

6. Suardi, A.; Stefanoni, W.; Alfano, V.; Bergonzoli, S.; Pari, L. Equipping a Combine Harvester with Turbine Technology Increases the Recovery of Residual Biomass from Cereal Crops via the Collection of Chaff. Energies 2020, 13, 1572. [CrossRef]

7. Paiano, A.; Lagioia, G. Energy potential from residual biomass towards meeting the EU renewable energy and climate targets. The Italian case. Energy Policy 2016, 91, 161-173. [CrossRef]

8. European Union (EU). Renewable Energy Directive II (EU) 2018/2001 11th December 2018. Available online: https://eur-lex.europa.eu/legal-content/IT/TXT/PDF/?uri=CELEX:32018L2001\&from=IT (accessed on 10 January 2020).

9. Italian Ministry of Economic Development. Guidelines for The Authorization of Power Plants Powered by Renewable Energies (In Italian). Available online: https:/www.gazzettaufficiale.it/eli/id/2010/09/18/ 10A11230/sg (accessed on 10 January 2020).

10. Lazio region (Italy). Regional Energy Plan. Available online: http://www.regione.lazio.it/prl_ambiente/?vw= contenutidettaglio\&id $=140$ (accessed on 10 January 2020).

11. Suardi, A.; Latterini, F.; Alfano, V.; Palmieri, N.; Bergonzoli, S.; Pari, L. Analysis of the Work Productivity and Costs of a Stationary Chipper Applied to the Harvesting of Olive Tree Pruning for Bio-Energy Production. Energies 2020, 13, 1359. [CrossRef]

12. ISTAT. Agriculture Statistics. Available online: https://www.istat.it/it/ (accessed on 1 March 2020).

13. Magagnotti, N.; Pari, L.; Picchi, G.; Spinelli, R. Technology alternatives for tapping the pruning residue resource. Bioresour. Technol. 2013, 128, 697-702. [CrossRef]

14. Spinelli, R.; Magagnotti, N.; Nati, C.; Cantini, C.; Sani, G.; Picchi, G.; Biocca, M. Integrating olive grove maintenance and energy biomass recovery with a single-pass pruning and harvesting machine. Biomass Bioenergy 2011, 35, 808-813. [CrossRef]

15. Gasol, C.M.; Gabarrell, X.; Rigola, M.; González-García, S.; Rieradevall, J. Environmental assessment:(LCA) and spatial modelling (GIS) of energy crop implementation on local scale. Biomass Bioenergy 2011, 35, 2975-2985. [CrossRef]

16. Dyjakon, A.; García-Galindo, D. Implementing agricultural pruning to energy in europe: Technical, economic and implementation potentials. Energies 2019, 12, 1513. [CrossRef]

17. Pari, L. Agricultural waste energy exploitation in Lazio Region. In Proceedings of the 2nd World Conference on Biomass for Energy, Industry and Climate Protection, Rome, Italy, 10-14 May 2004.

18. González-García, S.; Dias, A.C.; Clermidy, S.; Benoist, A.; Maurel, V.B.; Gasol, C.M.; Gabarrell, X.; Arroja, L. Comparative environmental and energy profiles of potential bioenergy production chains in Southern Europe. J. Clean. Prod. 2014, 76, 42-54. [CrossRef]

19. Delivand, M.K.; Cammerino, A.R.B.; Garofalo, P.; Monteleone, M. Optimal locations of bioenergy facilities, biomass spatial availability, logistics costs and GHG (greenhouse gas) emissions: A case study on electricity productions in South Italy. J. Clean. Prod. 2015, 99, 129-139. [CrossRef]

20. Jeong, J.S.; Ramírez-Gómez, Á. A multicriteria GIS-based assessment to optimize biomass facility sites with parallel environment-A case study in Spain. Energies 2017, 10, 2095. [CrossRef]

21. García-Galindo, D.; Dyjakon, A.; Cay Villa-Ceballos, F. Building Variable Productivity Ratios for Improving Large Scale Spatially Explicit Pruning Biomass Assessments. Energies 2019, 12, 957. [CrossRef]

22. Costa, F.R.; Ribeiro, C.A.A.S.; Marcatti, G.E.; Lorenzon, A.S.; Teixeira, T.R.; Domingues, G.F.; de Castro, N.L.M.; dos Santos, A.R.; Soares, V.P.; Mota, P.H.S.; et al. GIS applied to location of bioenergy plants in tropical agricultural areas. Renew. Energy 2020, 153, 911-918. [CrossRef]

23. Charis, G.; Danha, G.; Muzenda, E. A review of the application of GIS in biomass and solid waste supply chain optimization: Gaps and opportunities for developing nations. Proc. Int. Conf. Ind. Eng. Oper. Manag. 2018, 2018, 42-52. [CrossRef]

24. Abreu, M.; Reis, A.; Moura, P.; Fernando, A.L.; Luís, A.; Quental, L.; Patinha, P.; Gírio, F. Evaluation of the potential of biomass to energy in Portugal-conclusions from the CONVERTE project. Energies 2020, 13, 937. [CrossRef]

25. López-Rodríguez, F.; Sanz-Calcedo, J.G.; Moral-García, F.J. Spatial analysis of residual biomass and location of future storage centers in the southwest of Europe. Energies 2019, 12, 1978. [CrossRef] 
26. Picchio, R.; Proto, A.R.; Civitarese, V.; Di Marzio, N.; Latterini, F. Recent Contributions of Some Fields of the Electronics in Development of Forest Operations Technologies. Electronics 2019, 8, 1465. [CrossRef]

27. Statuto, D.; Tortora, A.; Picuno, P. A GIS approach for the quantification of forest and agricultural biomass in the Basilicata region. J. Agric. Eng. 2013, 44, 627-631. [CrossRef]

28. Rodríguez, R.; Gauthier-Maradei, P.; Escalante, H. Fuzzy spatial decision tool to rank suitable sites for allocation of bioenergy plants based on crop residue. Biomass Bioenergy 2017, 100, 17-30. [CrossRef]

29. Zhang, X.; Fu, J.; Lin, G.; Jiang, D.; Yan, X. Switchgrass-based bioethanol productivity and potential environmental impact from marginal lands in China. Energies 2017, 10, 260. [CrossRef]

30. Amirante, R.; Clodoveo, M.L.; Distaso, E.; Ruggiero, F.; Tamburrano, P. A tri-generation plant fuelled with olive tree pruning residues in Apulia: An energetic and economic analysis. Renew. Energy 2016, 89, 411-421. [CrossRef]

31. Zhang, B.; Hastings, A.; Clifton-Brown, J.C.; Jiang, D.; Faaij, A.P.C. Modelled spatial assessment of biomass productivity and technical potential of Miscanthus $\times$ giganteus, Panicum virgatum L. and Jatropha on marginal land in China. GCB Bioenergy 2020. [CrossRef]

32. Lozano-García, D.F.; Santibañez-Aguilar, J.E.; Lozano, F.J.; Flores-Tlacuahuac, A. GIS-based modeling of residual biomass availability for energy and production in Mexico. Renew. Sustain. Energy Rev. 2020, 120. [CrossRef]

33. Perpiñá, C.; Alfonso, D.; Pérez-Navarro, A.; Peñalvo, E.; Vargas, C.; Cárdenas, R. Methodology based on Geographic Information Systems for biomass logistics and transport optimisation. Renew. Energy 2009, 34, 555-565. [CrossRef]

34. Sánchez-García, S.; Athanassiadis, D.; Martínez-Alonso, C.; Tolosana, E.; Majada, J.; Canga, E. A GIS methodology for optimal location of a wood-fired power plant: Quantification of available woodfuel, supply chain costs and GHG emissions. J. Clean. Prod. 2017, 157, 201-212. [CrossRef]

35. Khan, S.; Mohiuddin, K. Evaluating the parameters of ArcGIS and QGIS for GIS Applications. Int. J. Adv. Res. Sci. Eng. 2018, 7, 582-594.

36. Tommasi, A.; Cefalo, R.; Grazioli, A.; Pozzetto, D.; Alvarez Serrano, Y.M.; Zuliani, M. Optimization of a Co-generative Biomass Plant Location Using Open Source GIS Techniques. Technical, Economical and Environmental Validation Methodology. New Adv. GNSS 3D Spat. Tech. 2018. [CrossRef]

37. Picchio, R.; Latterini, F.; Mederski, P.S.; Venanzi, R.; Karaszewski, Z.; Bembenek, M.; Croce, M. Comparing accuracy of three methods based on the gis environment for determining winching areas. Electronics 2019, 8, 53. [CrossRef]

38. Picchio, R.; Pignatti, G.; Marchi, E.; Latterini, F.; Benanchi, M.; Foderi, C.; Venanzi, R.; Verani, S. The application of two approaches using GIS technology implementation in forest road network planning in an Italian mountain setting. Forests 2018, 9, 277. [CrossRef]

39. Hadidi, L.A.; Omer, M.M. A financial feasibility model of gasification and anaerobic digestion waste-to-energy (WTE) plants in Saudi Arabia. Waste Manag. 2017, 59, 90-101. [CrossRef]

40. Khan, M.J.; Hasan, S.A. GiS-Based Screening Model of coastal city Karachi for plantation of Biofuel Source. Sci. Rep. 2020, 10, 1-7. [CrossRef]

41. Chalkias, C.; Lasaridi, K. Benefits from GIS based modelling for municipal solid waste management. In International Waste Management; Kumar, S., Ed.; INTECH Open Access Publisher: London, UK, 2011; Volume 1, pp. 417-434. ISBN 9533074698.

42. Waewsak, J.; Ali, S.; Gagnon, Y. Site suitability assessment of para rubberwood-based power plant in the southernmost provinces of Thailand based on a multi-criteria decision-making analysis. Biomass Bioenergy 2020, 137, 105545. [CrossRef]

43. Haase, M.; Rösch, C.; Ketzer, D. GIS-based assessment of sustainable crop residue potentials in European regions. Biomass Bioenergy 2016, 86, 156-171. [CrossRef]

44. Comber, A.; Dickie, J.; Jarvis, C.; Phillips, M.; Tansey, K. Locating bioenergy facilities using a modified GIS-based location-allocation-algorithm: Considering the spatial distribution of resource supply. Appl. Energy 2015, 154, 309-316. [CrossRef]

45. Franco, C.; Bojesen, M.; Hougaard, J.L.; Nielsen, K. A fuzzy approach to a multiple criteria and Geographical Information System for decision support on suitable locations for biogas plants. Appl. Energy 2015, 140, 304-315. [CrossRef] 
46. Valenti, F.; Liao, W.; Porto, S.M.C. A GIS-based spatial index of feedstock-mixture availability for anaerobic co-digestion of Mediterranean by-products and agricultural residues. Biofuels Bioprod. Biorefining 2018, 12, 362-378. [CrossRef]

47. Valenti, F.; Porto, S.M.C.; Dale, B.E.; Liao, W. Spatial analysis of feedstock supply and logistics to establish regional biogas power generation: A case study in the region of Sicily. Renew. Sustain. Energy Rev. 2018, 97, 50-63. [CrossRef]

48. QGIS Geographic Information System. Open Source Geospatial Foundation Project. Available online: http://qgis.org (accessed on 6 June 2020).

49. Indian National Centre for Ocean Information Services. Available online: https://io50.incois.gov.in/ documents/ITCOocean//Installation_Manuals_QGIS.pdf (accessed on 1 June 2020).

50. Pari, L.; Alfano, V.; Garcia-Galindo, D.; Suardi, A.; Santangelo, E. Pruning biomass potential in Italy related to crop characteristics, agricultural practices and agro-climatic conditions. Energies 2018, 11, 1365. [CrossRef]

51. EU Agroinlog - Integrated Biomass Logistic Centres fo the Agro-Industry. Available online: http://agroinlogh2020.eu/en/home/ (accessed on 16 April 2020).

52. Suardi, A.; Latterini, F.; Alfano, V.; Palmieri, N.; Bergonzoli, S.; Karampinis, E.; Kougioumtzis, M.A.; Grammelis, P.; Pari, L. Machine Performance and Hog Fuel Quality Evaluation in Olive Tree Pruning Harvesting Conducted Using a Towed Shredder on Flat and Hilly Fields. Energies 2020, 13, 1713. [CrossRef]

53. Italian Ministry of Environment Territory and Sea. Italian National Geoportal. Available online: http: //www.pcn.minambiente.it/mattm/servizio-di-scaricamento-wcs/ (accessed on 10 January 2020).

54. Lazio Region. Lazio Region Geoportal. Available online: https:/geoportale.regione.lazio.it/geoportale/ (accessed on 10 January 2020).

55. Palmieri, N.; Suardi, A.; Alfano, V.; Pari, L. Circular Economy Model: Insights from a Case Study in South Italy. Sustainability 2020, 12, 3466. [CrossRef]

56. Cundiff, J.S.; Grisso, R.D.; Shapouri, H. Economic Analysis of two Receiving Facility Designs for a Bioenergy Plant. In Proceedings of the 2007 ASAE Annual Meeting 2007, Minneapolis, MN, USA, 17-20 June 2007; American Society of Agricultural and Biological Engineers: St. Joseph, MI, USA, 2007.

57. QGIS plugin repository, Network Analysis Tool. Available online: https://docs.qgis.org/3.4/en/docs/training manual/vector_analysis/network_analysis.html (accessed on 19 June 2020).

58. Acampora, A.; Croce, S.; Assirelli, A.; Del Giudice, A.; Spinelli, R.; Suardi, A.; Pari, L. Product contamination and harvesting losses from mechanized recovery of olive tree pruning residues for energy use. Renew. Energy 2013, 53, 350-353. [CrossRef]

59. Pari, L.; Suardi, A.; Santangelo, E.; García-Galindo, D.; Scarfone, A.; Alfano, V. Current and innovative technologies for pruning harvesting: A review. Biomass Bioenergy 2017, 107, 398-410. [CrossRef]

60. Toscano, G.; Alfano, V.; Scarfone, A.; Pari, L. Pelleting vineyard pruning at low cost with a mobile technology. Energies 2018, 11, 2477. [CrossRef]

61. Nati, C.; Boschiero, M.; Picchi, G.; Mastrolonardo, G.; Kelderer, M.; Zerbe, S. Energy performance of a new biomass harvester for recovery of orchard wood wastes as alternative to mulching. Renew. Energy 2018, 124, 121-128. [CrossRef]

62. Forleo, M.B.; Palmieri, N.; Suardi, A.; Coaloa, D.; Pari, L. The eco-efficiency of rapeseed and sunflower cultivation in Italy. Joining environmental and economic assessment. J. Clean. Prod. 2018, 172, 3138-3153. [CrossRef]

63. Schweier, J.; Blagojević, B.; Venanzi, R.; Latterini, F.; Picchio, R. Sustainability assessment of alternative strip clear cutting operations for wood chip production in renaturalization management of pine stands. Energies 2019, 12, 3306. [CrossRef]

64. Schweier, J.; Magagnotti, N.; Labelle, E.R.; Athanassiadis, D. Sustainability Impact Assessment of Forest Operations: A Review. Curr. For. Reports 2019, 5, 101-113. [CrossRef]

65. Spinelli, R.; Lombardini, C.; Pari, L.; Sadauskiene, L. An alternative to field burning of pruning residues in mountain vineyards. Ecol. Eng. 2014, 70, 212-216. [CrossRef]

66. Avraamides, M.; Fatta, D. Resource consumption and emissions from olive oil production: A life cycle inventory case study in Cyprus. J. Clean. Prod. 2008, 16, 809-821. [CrossRef] 
67. Jacometti, M.A.; Wratten, S.D.; Walter, M. Management of understorey to reduce the primary inoculum of Botrytis cinerea: Enhancing ecosystem services in vineyards. Biol. Control 2007, 40, 57-64. [CrossRef]

68. Testa, R.; Foderà, M.; Di Trapani, A.M.; Tudisca, S.; Sgroi, F. Choice between alternative investments in agriculture: The role of organic farming to avoid the abandonment of rural areas. Ecol. Eng. 2015, 83, 227-232. [CrossRef] 